IZA DP No. 8041

Can US Coordination Failure Explain Why Americans Work So Much More than Europeans?

Maurice Schiff

March 2014 


\title{
Can US Coordination Failure Explain Why Americans Work So Much More than Europeans?
}

\author{
Maurice Schiff \\ IZA Research Fellow
}

Discussion Paper No. 8041

March 2014

\author{
IZA \\ P.O. Box 7240 \\ 53072 Bonn \\ Germany \\ Phone: +49-228-3894-0 \\ Fax: +49-228-3894-180 \\ E-mail: iza@iza.org
}

\begin{abstract}
Any opinions expressed here are those of the author(s) and not those of IZA. Research published in this series may include views on policy, but the institute itself takes no institutional policy positions. The IZA research network is committed to the IZA Guiding Principles of Research Integrity.

The Institute for the Study of Labor (IZA) in Bonn is a local and virtual international research center and a place of communication between science, politics and business. IZA is an independent nonprofit organization supported by Deutsche Post Foundation. The center is associated with the University of Bonn and offers a stimulating research environment through its international network, workshops and conferences, data service, project support, research visits and doctoral program. IZA engages in (i) original and internationally competitive research in all fields of labor economics, (ii) development of policy concepts, and (iii) dissemination of research results and concepts to the interested public.
\end{abstract}

IZA Discussion Papers often represent preliminary work and are circulated to encourage discussion. Citation of such a paper should account for its provisional character. A revised version may be available directly from the author. 


\title{
ABSTRACT
}

\section{Can US Coordination Failure Explain Why Americans Work So Much More than Europeans?}

\begin{abstract}
Prescott (2004) argues that Europeans work much less than Americans because of higher taxes and that they would gain significantly by charging US taxes and working as much as Americans. I argue that the opposite may be true and that Americans work more than Europeans due to a coordination failure. Studies show that utility falls with other people's income, a negative externality that is internalized in Europe through laws on the minimum amount of vacation time (and maximum hours of work), something unthinkable in the US. Thus, Americans may be stuck in an "overworking trap" and would gain by working less. A simple model and data on work time are used to obtain an estimate of the US welfare gain from reducing its work time to Europe's level. On the other hand, if neither EU nor US work time is optimal, then the sign of the EU-to-US welfare difference is positive (ambiguous) if EU work time is greater (smaller) than the optimum, while simulations show that even in the latter case, EU welfare is greater than US welfare if, relative to the optimum, the EU work 'shortage' is smaller than the US work 'surplus'.
\end{abstract}

JEL Classification: D70, J22

Keywords: $\quad$ work, leisure, Europe, US coordination failure

Corresponding author:

Maurice Schiff

E-mail: schiffmaurice@yahoo.com 


\section{Introduction}

Americans typically work much more than Europeans. Possible explanations for the difference in time devoted to work are different preferences, different incentives and coordination failure. The first reason provides little if any information unless the reason for the difference in tastes is clarified. As Stigler and Becker (1977) argue, a difference in behavior attributed to a difference in tastes can usually be explained by a difference in incentives and/or income (where both include the value of time). They did not consider the issue of social interactions and coordination failure, though the former was examined in Becker (1974). The second reason why Europeans work less than Americans is examined in Prescott (2004). He finds that it can be explained by Europe's higher taxes, particularly the marginal income tax and the consumption tax. He concludes that Europe's higher taxes led to a lower labor supply and welfare level than could be achieved under US taxes. ${ }^{1}$ Olovsson (2003) obtains a similar result for Sweden. This note, on the other hand, focuses on the third reason, namely coordination failure.

A question is whether Europe's higher taxes are actually responsible for the lower supply of labor. France passed its first law on paid vacations in 1936 (as did Belgium). The law established a two-week minimum vacation time and a forty-hour workweek. The legal minimum vacation time was raised to three weeks in 1956, four weeks in 1969 and five weeks in 1982. France's current five-week minimum is shorter than Germany's, whose minimum vacation time is six weeks. No legal minimum exists in the US where average vacation time, about two weeks, is three weeks less than in France and four weeks less than in Germany. Moreover, Europe's number of holidays is about twice that in the US. Assuming the high marginal tax rates determine Europe's allocation of time to work would imply that quantitative restrictions on labor supply would not affect it, though increases in the legal minimum vacation time have not led to an increase in work time in the rest of the year; rather, they have resulted in a decrease in the total supply of labor. Thus, quantitative restrictions such as the legal minimum vacation time rather than high

\footnotetext{
${ }^{1}$ On the other hand, Europeans believe they have achieved a healthier balance between labor and leisure, and that Americans work too much. This view is supported by studies that show that Americans do not sleep enough and that this has a negative impact on their productivity (e.g., Webster 2008).
} 
taxes may have acted as the binding constraint on labor supply. ${ }^{2}$ This note focuses on quantitative restrictions (QR) on labor supply rather than on tax rates, though it briefly looks at a where taxes may also have affected the supply of labor.

The view examined in this note is that the US may be in an "overworking trap" where an inefficiently large allocation of time is devoted to labor due to a coordination failure, and that working less would be beneficial. ${ }^{3}$ Coordination failure may occur in the case of interdependent preferences. Cohen (2012) describes recent studies that show how important the income of people in a person's reference group is for that person's wellbeing. For instance, in an experiment conducted in the US, students were asked which of two situations they prefer: one where they earn $\$ 50,000$ and the others earn $\$ 25,000$, or one where they earn $\$ 100,000$ and the others earn $\$ 200,000$. The majority preferred the former, a response that is consistent with parameter values obtained in Section 3. Cohen also describes an empirical study in the US that shows that a woman is more likely to work if her sister’s husband earns more than her own husband. ${ }^{4}$

Interestingly, comparative wellbeing (envy) does not seem to extend to aspects of life that are less visible in terms of status, wealth and success in the eyes of society. In other

\footnotetext{
${ }^{2}$ Other factors than high marginal tax rates may affect labor supply, including labor market rigidity, greater in Europe than in the US and which should reduce productivity. The importance of these rigidities is unclear as labor is as productive in, say, France as in the US (OECD, 2012), though they might affect unemployment. Following Prescott (2004), I abstract from these issues here.

${ }^{3}$ Why a coordination failure? If people were offered, say, an additional week of vacation in exchange for a $2 \%$ reduction in salary (= 1 week out of 50 ), most might reject it, even though they might accept it if everyone else did. The reason is that someone obtaining more vacation time i) experiences a decline in relative income and thus a utility loss; ii) might be perceived as lacking commitment to the job, with potential negative career implications; and iii) has few if any people with whom to enjoy it since they are working, which reduces its value. Given that none of these three negative effects are present when everyone else also obtains more vacation time, a majority of people might want more vacation time if everyone else did. Assuming they do, a coordination failure exists since there is no mechanism to move the US economy from the private to the social equilibrium, except maybe through higher marginal income tax, but this is unlikely to be politically feasible. The opposite holds in Europe where governments set minimum vacation time.
}

${ }^{4}$ Becker (1974) examines behavioral implications of social interactions or interdependent preferences for, among others, intra-family income transfers, charity, and envy. He shows in the case of envy/hatred that predatory expenditures decline with an individual's own income and increase with the income of others, i.e., the propensity to engage in predatory activities declines with individuals' relative economic position. This paper examines the implication of social interactions in the case of envy for a different type of individual behavior, namely the extent of labor force participation. 
words, it does not extend to what Frey has termed "intrinsic" as opposed to "extrinsic" goods (e.g., Frey 1997), where the former consist of aspects such as a sense of purpose, relatedness, love, available quality time, etc., aspects that seem more important for individual wellbeing (Brooks 2012). ${ }^{5}$ For instance, the students mentioned above chose four weeks vacation when others obtained eight weeks, rather than two weeks when others obtained one week. In this case, having less than others did not matter.

In what follows, I assume a utility function that reflects the characteristics of individual preferences described above, i.e., utility declines with other people's average income but is unaffected by other people's leisure time.

A simple model is presented in Section 2, simulations are provided in Section 3, and Section 4 concludes.

\section{Model}

Assume an economy with homogeneous labor as the only factor of production. Individual income is given by

$Y=Y(L), Y_{L}>0$

where $L$ is the share of time individuals spend working.

Utility, which is concave in all its arguments, is given by:

$U=U(l, Y, y), U_{l}>0, U_{Y}>0, U_{y}<0, U_{Y}+U_{y}>0, U_{Y y}<0$

where $l=1-L$ is the share of time spent on leisure by any given individual, and $y$ is the average income of the other individuals.

\subsection{Private optimum}

Individuals maximize $U$ with respect to $l$, taking $y$ as given. The private optimum (Nash equilibrium) is given by:

\footnotetext{
${ }^{5}$ Ryan and Deci (2001) use a similar classification to describe the two main strands of research on wellbeing, the "hedonic" (pleasure-based) and the "eudaimonic" (human flourishing) strands, where wellbeing is a function of things consumed (Epicurius) under the former and a function of meaning and self-realization (Socrates, Plato, Aristotle) under the latter.
} 
$U_{l}^{P}=U_{Y} Y_{L}$

The private solution is sub-optimal because of a distortion associated with the negative externality of other people's income.

\subsection{Social Optimum}

In this case, the solution is:

$U_{l}^{S}=\left(U_{Y}+U_{y}\right) Y_{L}<U_{l}^{P}=U_{Y} Y_{L}$

The fact that $U_{l}^{S}<U_{l}^{P}$ implies that $l^{S}>l^{P}$. Thus, the share of time devoted to work (leisure) is lower (higher) at the social than at the private optimum.

\section{Simulations}

Section 3.1 provides specific functions for $Y$ and $U$, solves for labor and leisure levels for the private and social optimum, and uses data on these variables in the US and Europe to obtain numerical values for the parameters, for labor and leisure and for the US welfare gain of reducing working time to European levels. Section 3.2 examines US and Europe's welfare when Europe (US) work time is lower (higher) than the optimum. Section 3.3 examines whether the 'envy' parameter that is implicit in the student experiment (described in Section 1) is consistent with the values obtained in Section 3.1.

\subsection{Welfare Implications}

Assume $Y$ and $U$ are given by:

$Y=L$,

where units are defined such that labor's marginal product is equal to 1 .

Individual utility is given by:

$U=l^{\alpha} Y^{1-\alpha} y^{-\beta}, \beta \in(0,1-\alpha)$.

The private optimum is given by:

$l^{P}=\alpha, Y^{P}=L^{P}=1-\alpha, U^{P}=\alpha^{\alpha}(1-\alpha)^{1-\alpha-\beta}$.

The social optimum is given by: 
$l^{S}=\frac{\alpha}{1-\beta}>l^{P} ; Y^{S}=L^{S}=\frac{1-\alpha-\beta}{1-\beta}<Y^{P}=L^{P} ;$

$U^{S}=\left(\frac{\alpha}{1-\beta}\right)^{\alpha}\left(\frac{1-\alpha-\beta}{1-\beta}\right)^{1-\alpha-\beta}>U^{P}$.

The ratio of social to private utility, $V$, is given by:

$V \equiv \frac{U^{S}}{U^{P}}=\left(\frac{1}{1-\beta}\right)^{1-\beta}\left(\frac{1-\alpha-\beta}{1-\alpha}\right)^{1-\alpha-\beta}>1 \Leftrightarrow \beta>0$

It can be shown from (5) that $\frac{\partial V}{\partial \beta} \geq 0 \Leftrightarrow \beta \geq 0$. Since $V=1$, or $U^{S}=U^{P}$, for $\beta=0$, it follows that $V>1$, or $U^{S}>U^{P}$, for $\beta>0$. Moreover, $\frac{\partial^{2} V}{\partial \beta^{2}}>0, \forall \beta$, i.e., $V$ increases with $\beta$ at an increasing rate.

Following Olovsson (2003), Prescott (2004) and Cohen (2012), assume Europeans and Americans have identical preferences. The situation in the US (Europe) is assumed to correspond to the private (social) optimum. The reason is that, since a law that sets a minimum amount of vacation time employers must provide their employees would never be countenanced in the US, no mechanism exists for internalizing the negative externality associated with other people's (additional) work or income. On the other hand, given that they tend to accept government involvement in more areas than Americans, Europeans have been able to internalize the negative externalities of additional work. ${ }^{6}$

The OECD publishes information on the amount of time devoted to work, from which leisure time can be obtained. On average, the US has 141.1 days of leisure per year (including week-ends, holidays and vacation time), the Netherlands has 192.9 leisure days, Germany 190.9, Norway 187.5 and France 181.1.

\footnotetext{
${ }^{6}$ It could be argued that leisure time in Europe is greater than the optimal level, including in France where vacation time is among the highest. However, its current vacation time has not changed in 32 years, and though the workweek was reduced from 39 to 35 hours in 2000, France's legislators effectively did away with it in 2005 by allowing companies to negotiate new contracts intended to restore the 39-hour workweek.
} 
Netherlands and Germany's number of leisure days is about 36 percent higher than in the US, i.e., the ratio $\frac{l^{E}}{l^{U S}}=\frac{1}{1-\beta}=1.36$, with $\beta=.265$ and $l^{E}=.53$. The number of days spent on leisure in the US as a share of the total number of days in the year is $l^{U S}=\alpha=$ 0.39 . These parameter values imply that $V=1.04$. Thus, internalizing the negative externalities raises welfare by 4 percent. In the case of Norway, $\beta=.25$ and $V=1.035$. And in the case of France, $\beta=.227$ and $V=1.031$.

\subsection{Sub-optimal European Work Time}

As mentioned in Section 3.1, $\frac{\partial V}{\partial \beta} \geq 0 \Leftrightarrow \beta \geq 0$, and $V=1$ for $\beta=0$, so that $U^{E}>U^{U S}$ for $\beta>0$, where $\beta$ is a measure of the true negative externality. Assume Europe perceives this measure to be $\beta^{E} \neq \beta$, with $\beta^{E} \gtrless \beta \Leftrightarrow l^{E} \gtrless l^{S}$. ${ }^{7}$ Thus, as long as $l^{E}<l^{S}$, i.e., $\beta^{E}<\beta$, it follows that $U^{E}>U^{U S}$ (since $\beta^{E}>0, l^{U S}<l^{E}<l^{S}$ ). On the other hand, if $\beta^{E}>\beta$ and $l^{E}>l^{S}$, then $U^{E} \gtrless U^{U S}$, i.e., which of $U^{E}$ or $U^{U S}$ is greater is ambiguous.

Assume that $l^{E}>l^{S}$. In the first case in Section 3.1, $l^{E}=.53$. Assuming $l^{*}$ is the average of $l^{E}$ and $l^{U S}$, i.e., $l^{S}=.46$, it follows that $U^{E}=U^{U S}=.5524$. Similar results obtain in the other two cases. ${ }^{8}$

\subsection{Student Experiment}

In the experiment described in Section 1, students preferred the first offer of an own income (in USD thousands) $Y_{1}=50$ with others' average income $y_{1}=25$, to the second offer of $Y_{2}=100$ and $y_{2}=200$, implying - from equation (2) above - that $50^{1-\alpha} 25^{-\beta}>100^{1-\alpha} 200^{-\beta}$ or, equivalently, that $2^{1-\alpha} 8^{-\beta}<1$. For $\beta=.265\left(1^{\text {st }}\right.$ case in Section 3.1), $2^{1-\alpha} 8^{-\beta}=2^{.61} 8^{-.265}=.89<1$. For $\beta=.25$ ( $2^{\text {nd }}$ case), $2^{.61} 8^{-.25}=$ $.92<1$, and for $\beta=.227$ ( $3^{\text {rd }}$ case), $2^{.61} 8^{-.227}=.95<1$. Thus, our analysis is consistent with students' preference for the first offer.

\footnotetext{
${ }^{7}$ Another reason may be that some features of the labor market or tax system further reduce labor supply. For instance, firing employees is difficult and employers may prefer to hire part-time or temporary workers. ${ }^{8}$ The proportional difference between $U^{E}$ and $U^{U S}$ in these and other cases examined is never greater than .0009 .
} 


\section{Conclusion}

This note has argued that the US suffers from a coordination failure, resulting in excessive time being devoted to work because of an inability to internalize the negative externalities associated with other people's income, and that the opposite holds in Europe where laws about minimum vacation time (and maximum hours of work) exist. Thus, Americans are likely to be stuck in an "overworking trap," with too little time allocated to leisure and too much time allocated to work relative to their welfare-maximizing levels.

\section{References}

Becker, Gary S. 1974, “A Theory of Social Interactions.” Journal of Political Economy 82 (6): 1063-93.

Brooks, David. 2012. The Social Animal. The Hidden Sources of Love, Character and Achievement, New York: Random House.

Cohen, Daniel. 2012. Homo Economicus, Prophète (Égaré) des Temps Nouveaux. Paris: Albin Michel.

Frey, Bruno S., 1997. Not just for the money. An economic theory of personal motivation, E. Elgar, Cheltenham.

OECD. 2012. Labour Database, Paris.

Olovsson, Conny. 2003. "Why do Europeans work so little?” Manuscript. International Institute for Economic Studies, Stockholm University.

Prescott, Edward C. 2004. "Why Do Americans Work So Much More Than Europeans?” Federal Reserve of Minneapolis Quarterly Review

Ryan, Richard M. and Edward L. Deci. 2001. "On Happiness and Human Potentials: A Review of Research on Hedonic and Eudaimonic Well-Being," Annual Review of Psychology 52: 141-166 (February).

Stigler, George and Gary S. Becker. 1977. "De Gustibus Non Est Disputandum.” American Economic Review 67 (2): 76-90.

Webster, Molly. 2008. “Can You Catch Up on Lost Sleep?” Scientific American (May 6) 